\title{
スノーボードを利用した キネマティックGPSによる積雪深観測
}

\author{
菊地 慶太 1）風間 聡 2) \\ 1) 東北大学大学院工学研究科 \\ （干980-8579 宮城県仙台市青葉区荒巻字青葉 6-6-06） \\ 2) 東北大学大学院環境科学研究科 \\ （９980-8579 宮城県仙台市青葉区荒巻字青葉 6-6-20）
}

\begin{abstract}
GPSを用いて2006年から2007年の冬季から春季にかけて，山岳域（宮城蔵王）における積雪深分布を観測した， 山間部において積雪期から融雪期にかけて標高-積雪深分布データを得ることはこれまでほとんどなされておらず, これらのデータは，貴重である．観測には干渉測位の一つである連続キネマティック測位を用いた．この測位方法 は任意点のデータを一定時間間隔で取得できるのが特徴である。位置データ補間には最近隣法, 2 点幾何補間法を用 いた。そしてGPS測位および補間結果から地表面標高に対する詳細な積雪深分布データを得ることが出来た。測定 誤差には, 姿勢誤差, 計算誤差, 実地誤差, 観測誤差がある. それらの合計は, 最近隣法が $0.25 \mathrm{~m} \sim 0.41 \mathrm{~m}, 2$ 点幾 何補間法が $0.25 \mathrm{~m} \sim 0.40 \mathrm{~m}$ である. 測深棒と GPS測位による積雪深の比較では2点幾何補間法の場合，両者の差は $0.34 \mathrm{~m} \sim 1.10 \mathrm{~m}$ ，最近隣法の場合は $0.12 \mathrm{~m} \sim 0.30 \mathrm{~m}$ となった．最近隣法の場合，積雪深が $3 \mathrm{~m}$ 以上であれば相対誤差は 10 \%以下であり良好な值が得られた。つまり雪の多い場所，特に山間部において最近隣法を用いたGPS観測は有効 な手段である.
\end{abstract}

キーワード：キネマティック㵋位, 最近隣法, 2点幾何補間法, 積雪-標高曲線, 誤差評価

\section{I 、はじめに}

日本全土で一年間のうち積雪に覆われる地域は $50 \%$ にも達し, 雪は観光, ウインタースポーツをはじめ, 様々な産業に大きな影響を与える。また, 春先の融 雪水も貴重な水資源として重宝される。融雪水の多 くが山岳域からの融雪であるため, 山岳域の雪は白 いダムと形容される。

気候変動により融雪時期の変化が起き，代掻き期 の水不足が懸念されている。一方で, 2006-07シーズ ンには，全国において記録的な低温となり，20年振 りに記録的な豪雪に見舞われ (平成18年豪雪), 死 者・行方不明者は戦後 2 番目に多く 151 人, 負傷者は 2,100人を超えた (内閣府, 2006).このように, 積 雪は日本人の生活に密接に関わりがある。そのため, 積雪を有効利用し, 雪害の低減を図るにはより正確 な積雪深分布を知ることが重要である。その中でも 山岳域の積雪は積雪期には吹雪や降雪などの気候条 件, 雪崩の危険性や登山知識の必要性などの制約条
件により観測がほとんどなされていない。これは， 前述の問題を考えるうえで非常に重要な要素であ り, 山岳域のより詳細な積雪深分布を知る事が必要 である。

積雪深観測にはいくつかの方法がある.1つはスノー サーベイと呼ばれる方法である（(社）日本雪水学会 監修, 2005).これは最も単純な方法であり, 測深棒 を雪に挿入し観測する。この方法は水力電源地帯で はしばしば定期的に実施されている。実際に雪を掘 ることで積雪深を求める方法もある。松山（1998a） は新潟県巻機山に扔いてスノーサーベイを行い，高 度に対する積雪水量増加率 $\mathrm{a}$ を求め, その増加は線 形もしくは2次曲線的に増加することを明らかにし た。同様に松山（1998b）は日本全国において山岳地 域に扔いて決定された係数 a の結果をまとめた。村 上・山野井 (2003) も同様に, 利根川源流流域にあ る宝川森林理水試験地において高度に対する積雪水 量増加率を調査し, 高度と線形増加することを明ら 
かにした。また，島村ら（2005）は新潟県巻機山 に扔いて森林限界下, 森林限界上に扔いて測深棒に よるスノーサーベイを行い, 森林限界の上下での積 雪深分布の相違を明らかにした。この手法は気候条 件，地理的条件に影響を受けやすく，観測日は融雪 期である3月以降，また観測点も数点にとどまる。

2つ目は超音波型の積雪深計での固定点観測であ る。これは，主に気象庁が気象観測に用いている (気象庁，2006)。観測所数は300点弱程あるが $(2008$ 年7月24日時点), そのほとんどが標高の低い地点と なる（気象庁，2008）。観測所が標高1000mを超える ところはわずか 5 地点にとどまる.

ところで, GPS (Global Positioning System) は，1993年 7月9日に米連邦航空局により民間利用が認められて 以来，新たな測位技術として急速に発展を遂げてい る. GPS測位はGPS衛星と受信機との距離をもとに 位置を単独で観測するため, 測点間の見通しを必要 とせず，天候にも左右されずに詳細な空間デー夕を 取得できる。また初期作業以外ほぼ自動で測位が行 えるのが利点である. 現地観測, 各種計測において GPSで効率よくなおかつ高精度に測位を行うことが 可能となりGPSを用いた研究は多分野に渡りその有 用性が期待されている。

例えば，湾港工事や海上測量のためにGPSを用い たリアルタイム処理方式海上測位システムの開発 (浜田ら，1996）や，RTK（Real Time Kinematic）-GPSを 用いた地盤大変状の計測が行われ，その実用性が評価 されている (堀ら，2003）。また，源島・松井 (2003) はGPSによる施工管理を採用した大規模土工を紹介し ている.

そこで, 本研究ではそれらの利点を生かし, GPS を用いた積雪深観測から山岳域におけるより詳細な 積雪分布を調査し, 地表面の起伏変化と積雪深分布 の関係を調査することを目的とする。また，測定誤 差の検討を行うことで，その有用性の検証を行う。

\section{II. 研究対象領域・期間}

研究対象領域は, 宮城県刈田郡蔵王町, すみかわ スノーパーク入り口から刈田岳頂上までである。 図一1にその周辺図を示す. 刈田岳は北緯 $38^{\circ} 07^{\prime} 40^{\prime \prime}$,

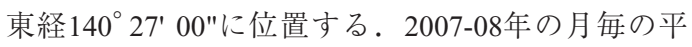
均気温は 11 月 $7.5{ }^{\circ} \mathrm{C}, 12$ 月 $3.3{ }^{\circ} \mathrm{C}, 1$ 月 $0.2{ }^{\circ} \mathrm{C}, 2$ 月 0.2 ${ }^{\circ} \mathrm{C}$, 3月 $4.8{ }^{\circ} \mathrm{C}$, 4月9. $8{ }^{\circ} \mathrm{C}$ である。ただしこれは地表 面標高112 m地点にある蔵王アメダス観測所の值で

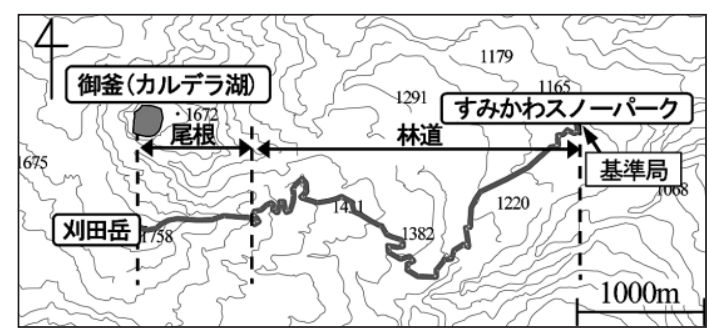

図-1 研究対象領域

Fig. 1 Study area.

あるため, 地表面標高増加につれ気温減率に従い気 温は低下する。対象区間の地表面標高は掞よそ1100 $\mathrm{m} \sim 1760 \mathrm{~m}$ であり, 水平測位距離は約6000 mであ る. 約 $1100 \mathrm{~m}$ 約 $1500 \mathrm{~m}$ までは幅 5 メートルほどの 林道が続き, 両側は高さ $5 \mathrm{~m}$ ほどのナラやブナ・カ エデなどの落葉樹で覆われている。 そして， $1550 \mathrm{~m}$ 以降は蔵王エコーラインを横切り, 刈田岳の尾根と なる. 尾根は, 一帯にアオモリトドマツなどの常緑 針葉樹, 八イマツなどの常緑低木地帯が広がり, 山 頂付近には植生限界地帯が広がる。対象区間の傾斜 方向は, 概ね東南東向きである. 対象領域の採用理 由として, 距離が近く測位に行きやすく, 土地勘が あること，また宮城県内では有数の高山であること， スキー場が併設されているため登りやすいことが挙 げられる。

測位は2007年8月29日，2008年1月29日，2月19日， 3月4日，4月3日，4月13日の計6回実施した。 8 月29 日は無積雪状態での観測であり，これが地表面標高 データとなり，その他の日のデータは積雪面標高と なる１月29日，2月19日は積雪期に当たり，積雪量 は増加傾向にある. 山頂付近の低木は積雪によりほ とんどが隠れ， $10 \mathrm{~m}$ 以上の背の高い木のみが散在し ている状態となる。一方3月4日，4月3日，4月13日は 融雪期となり積雪量は経時的に減少傾向となる。3月 4日，4月3日は対象区間全域が積雪に覆われていた が，4月13日は地表面標高が低い地域で地面が露出し ている部分も見受けられた。対象区間中腹において も開けている部分，または，傾斜方向による日射の 影響などにより岩肌が露出している部分が存在した.

\section{GPS測位}

2つ以上のGPS受信機を用いるGPS測位は，衛星から 発信されるL1帯 $(1575.42 \mathrm{MHz}), \mathrm{L} 2$ 帯 $(1227.6 \mathrm{MHz})$ と呼ばれる測位用電波を基準局, 受信局の2つの受信 
機によって受信し，これらの電波の位相を測定し， その位相の差を利用して，受信機間の相対べクトル を求める方法である。キネマティック測位に関して 言えば，受信局は移動局となる。

測位には連続キネマティック測位を採用した。キ ネマティック測位の定義は様々であるが，今回は各 測点での観測時間を短縮した干渉測位方式をキネマ ティック測位とする。その中でも，今回の測位では 連続キネマティック測位を用いた。この方法では, 1 基のGPS受信機により測位を行うカーナビゲーショ ンのような単独測位より高精度な測位が可能である.

この方式について述べる前に，まず，その拡張元 となるストップアンドゴー方式について述べる，ス トップアンドゴー方式は, 測点またはその周辺の 2 点 に受信機を設置して位置を確定する。その後基準局 はそのままにして，もう一方の受信機を測点に移動 して測点と基準局との相対位置を測定していく。こ の間，電波を継続的に受信するところが特徵である。 継続的受信の利点は, 最初に確定した整数值バイア 又（後述）を保存でき, 測点ごとの確定を必要とし ないことである．そのため各測点の測定は数秒から 1分程度で行うことができる。ここで，整数值バイア スについて説明を付け加える。干渉測位では各受信 機で搬送波位相を積算するが，単独即位のように搬 送波はサイン波の連続であるため，原点となる目印 が存在しない。そのため積算值の初期値がわからな くなり, 整数波数の不確定が生じる.これを整数值 バイアスという。干渉測位では観測前の初期化の段 階で，これを決定することで位置を求める。万が一 測位途中で電波が途切れた時には，順調に測位が終 了した測点に戻り同様の作業を繰り返す。

連続キネマティック測位はストップアンドゴー方 式の連続的な測位方式への拡張であり, 電波を継続 的に受信することで，受信機の移動経路中の任意の 位置を求める方式である。従来の測量方法では, 測 点ごとに一定時間停止して行わなければならないの に対し，この方法では，任意の点を移動しながら一 定時間間隔で測位できる。初期作業として, 移動局 の初期化を行うことで, 基準局から半径最大 $10 \mathrm{~km}$ 程度までなら，観測者は特別な操作なしに公称 \pm 10 $\mathrm{cm}$ 程度の水平精度での測位を行うことができる。な お, 衛星の捕捉高度は地表面から $10^{\circ}$ 以上, 観測の際 の衛星捕捉数は4個以上であった。

本研究では基準局は三脚に固定し，移動局を背負 い，雪山をスノーボードにより滑走する形で測位を

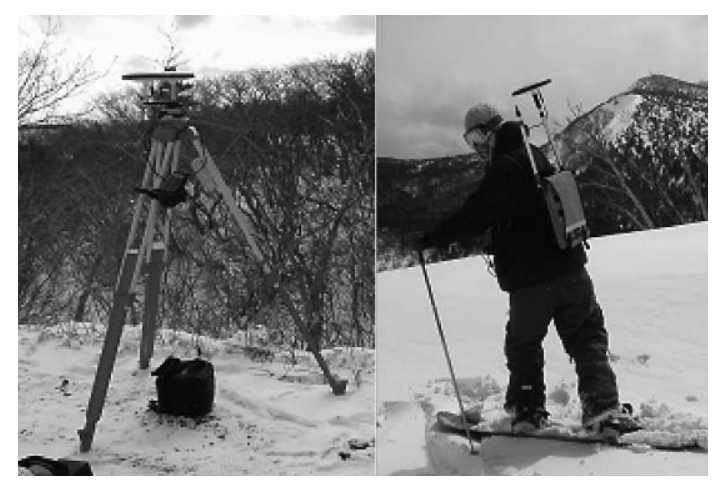

図－2 GPS基準局 (左) と移動局 (右)

Fig. 2 GPS Receivers.

実施した。なお，基準局の位置に関しては，観測後 の解析において電子基準点を用いてスタティック測 位を行う（後述）ため，三角点などは基準にせず， スキー場入り口付近に設置した。 スノーボードは雪 面との接触面積が大きく沈み込みの誤差が少ないこ と, 下山の時間短縮に有効であるという理由から採 用した。

具体的な操作としては，まず無積雪期に地表面 デー夕を取得する。その後, 雪が存在している時期 に同じようにデー夕を取得することで，積雪面標高 デー夕を得ることができる。積雪深は, 無積雪期の 8月29日の地表面標高デー夕とその他の観測日の積雪 面標高データの差をとることで求めた。ここで, 積 雪期に測位した測線は無積雪期のそれに対し，ほほ 片側 $2.5 \mathrm{~m}$ ，両側 $5 \mathrm{~m}$ の範囲内に含まれる.

GPS測位にはThales Navigation社のProMark3を用 いた。基準局とスタティック測位を行う際，電子基 準点を用いた，電子基準点は国土地理院により管理 されており，配置数は日本全土で約1200点に扔よび， 世界でもトップクラスである. 水平方向の測位誤差 も非常に小さく2〜3 $\mathrm{mm}$ である。これは, 現在の GPS技術からすると世界最高水準であり，その優れ た精度から地殼変動の観測にも用いられている。 図一2に測位機器を示す。

\section{IV 。位置データ補間}

\section{GPSデータ}

GPS測位により得られたデータは, 解析ソフト GNSS Solutionsによる計算の結果, WGS84座標系に より表される緯度経度情報から, 平面直角座標 (JGD2000）（x,y,z）に変換される，積雪深は測位日 
間の $\mathrm{z}$ 座標の差から求まるが，測位法の性質上，任 意点を測位していくため, 毎回全く同じ地点のデー 夕を収集することは困難となる。そのため，測位日 間で位置データ補間を行い, 積雪深を求めることが 必要となる。そこで, 本研究に扔いては, 補間に最 近隣法抒よび2点幾何補間法を用いた。

\section{2. 最近隣法}

最近隣法は, 積雪面上のある測位点から最も近い 地表面標高上の点を抽出する補間方法である.

手順としては，ある積雪面データについて地表面 データとの水平距離をすべて求める。そこで最近傍 点を選ぶ。その2点間の標高差を積雪深として算出 する。

本研究では補間により得られたデータのうち2点間 距離がそれぞれ $0.5 \mathrm{~m}$ 以下， $1.0 \mathrm{~m}$ 以下， $1.5 \mathrm{~m}$ 以下の データにおいて積雪深を算出した.

この方法は最も単純な方法であり, 積雪面標高デー 夕に対し，採用した地表面標高データが等高線方向 にずれている場合，良好な近似值が得られるが，傾 斜方向のずれが大きい場合，標高分が䛊差に含まれ るため位置デー夕処理による誤差が大きくなる欠点 がある。

\section{2点幾何補間法}

2点幾何補間法では，ある積雪面標高デー夕に対し 近傍の地表面標高データ2点から相似則を用いて標高 を補間する，近傍の 2 点からの補間は図一3のような 各観測点を考える。まず，積雪面座標と地表面座標 から $\mathrm{x}, \mathrm{y}$ 座標が最も近い点を探す。その $\mathrm{z}$ 座標の差 分を仮の積雪深とする。ここで，積雪深を観測区間

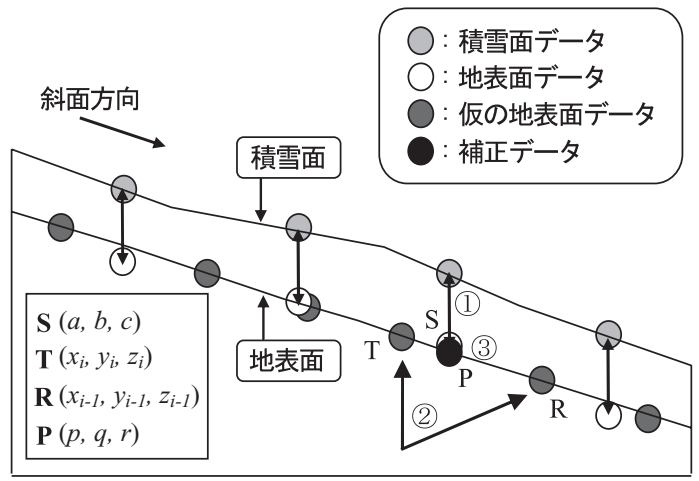

図 -3 2点幾何補間法

Fig. 3 The 2-point geometric method.
で一様であると仮定し, 積雪面Z座標から地表面 $\mathrm{z}$ 座 標を差し引く (図一31) . これを仮の地表面座標 $\mathrm{S}(a$, $b, c)$ とする。続いて, この点 $\mathrm{S} の \mathrm{Z}$ 座標から最も近 い地表面の点を前後2点 $\mathrm{T}\left(x_{i-1}, y_{i-1}, z_{i-1}\right), \mathrm{R}\left(x_{i}, y_{i}, z_{i}\right)$ を抽出する (図一32)）。この2点を通る直線と点 $\mathrm{S}$ と の距離が最小距離になるような直線TR上の点 $\mathrm{P}(p, q$, r) を補正値とする (図一3(3)). 点 $\mathrm{P}$ の座標を求める 式は以下の式 (1)〜 (3) のようになる。これらはPが 直線TR上にあること, 直線TRと直線PSが直交する ことを用いれば求まる。

$$
\begin{aligned}
& p=\frac{\left(b-y_{i}\right)\left(x_{i}-x_{i-1}\right)\left(y_{i}-y_{i-1}\right)+a\left(x_{i}-x_{i-1}\right)^{2}+x_{i}\left(y_{i}-y_{i-1}\right)^{2}}{\left(x_{i}-x_{i-1}\right)^{2}+\left(y_{i}-y_{i-1}\right)^{2}} \\
& q=\frac{\left(a-x_{i}\right)\left(x_{i}-x_{i-1}\right)\left(y_{i}-y_{i-1}\right)+y_{i}\left(x_{i}-x_{i-1}\right)^{2}+b\left(y_{i}-y_{i-1}\right)^{2}}{\left(x_{i}-x_{i-1}\right)^{2}+\left(y_{i}-y_{i-1}\right)^{2}} \\
& r=z_{i}+\frac{\left(q-y_{i}\right)\left(z_{i-1}-z_{i}\right)}{\left(y_{i-1}-y_{i}\right)}
\end{aligned}
$$

求めた $r$ を補正前の積雪面標高座標から差し引き積 雪深を得る。これは計測が傾斜方向に行われていれ ば，精度の高い補間ができるため, 整備された単純 な斜面を滑り降りてくる際には有効な補間方法であ る。しかし蛇行をして等高線と平行な方向に動くよ うなことがあると, 積雪面標高デー夕から地表面標 高デー夕間を結ぶ直線に下ろす垂線が等高線方向の 成分を持ってしまい，誤差が生じる。

\section{V 。䛊差の評侕}

\section{1. 誤差}

GPSによる積雪深観測において生じる誤差は，姿 勢誤差, 計算誤差, 実地誤差, 観測誤差が考えられ る。それらの誤差について, 次項のような方法によ り評価した。また，2008年2月19日には，実際の積雪 域上のGPS測位を行う際，同時に測深棒による積雪 深の計測を行い, GPS測位の結果と比較，検証を実 施した。測深棒にはBlack Diamond社製Quick Draw Guide Probe 300 （最大計測深 $300 \mathrm{~cm}$ ）を用いた。計測 は一地点に対し一回のみの計測を実施した。

\section{2. 姿勢誤差}

これは, GPS受信機を背負い, スノーボードで滑 る際の姿勢変化によって起きる標高方向の誤差であ る。これは, 台車にGPS受信機を固定し, 上下変化 の起こらない状態で測位を行ったものと, 実際に背 
負いながらの測位を同経路で実施したものの差であ る。測位方法には積雪深観測と同様に連続キネマ ティック測位を実施した。その上で標高差を比較す ることにより，誤差を検討した。なお，比較する際， $\mathrm{IV}$ 章に示した通り位置データ間にずれが生じる。そ

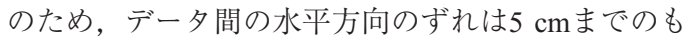
のを採用した。

\section{3. 計算誤差}

計算誤差は, 積雪面標高データと地表面標高デー 夕から積雪深を求める際の各補間方法により生じる 誤差である．補間の際にペアになる地表面標高デー 夕と，積雪深標高データに等高線方向のずれが生じ ていた場合，ずれの分の標高も積雪深に含まれてし まうためこのような誤差が生じる。この検証では, まず一様乱数を用いて斜面幅 $3 \mathrm{~m}$, 全長 $2000 \mathrm{~m}$ の模 擬斜面上に地表面標高データをプロットした。同様 の方法で斜面幅 $5 \mathrm{~m}$, 全長 $2000 \mathrm{~m}$ の積雪面デー夕を 模擬斜面上に作成した。斜面幅に関しては，積雪面 データ取得にスノーボードを利用するため蛇行する

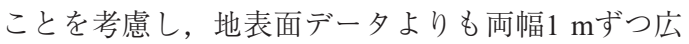
くとった。 な拐, 補間結果によって求めた積雪深デー 夕が数個〜数十個と多くないため, 誤差平均の算出 には $t$ 分布を用いて統計解析を行った。

斜面斜度は，現地に押いてGPS測位の結果から代 表斜度 $4^{\circ}, 8^{\circ}, 16^{\circ}$ とした。なお代表斜度は測位区間 を林道（地表面標高 $1100 \mathrm{~m} \sim 1500 \mathrm{~m}$ )，低灌木 $(1500 \mathrm{~m} \sim 1700 \mathrm{~m})$ ，森林限界 $(1700 \mathrm{~m} \sim 1780 \mathrm{~m})$ に区切り, それぞれの水平移動距離一標高グラフに おいて最小二乗法線形近似により求めた。

\section{4. 実地誤差}

実地誤差は, 現地で測位を行う際, 距離や大気の 影響により生じる誤差である。検証として，予め受 信局の高さを正確に $1 \mathrm{~m}$ 測り, 台座に固定した。そ して，その状態でGPS測位を実施した。誤差が $0 \mathrm{~m}$ であれば，すべての観測点の測位結果が $1 \mathrm{~m}$ となる はずである。その誤差を比較し, 評価した。なお， 観測点は約50点である.

\section{5. 観測誤差}

対象領域の斜面は一様ではなく, 凸凹が随所に存 在する。また, GPS測位と測深棒の観測位置は若干 ずれが生じている。そのため, 観測誤差が生じると

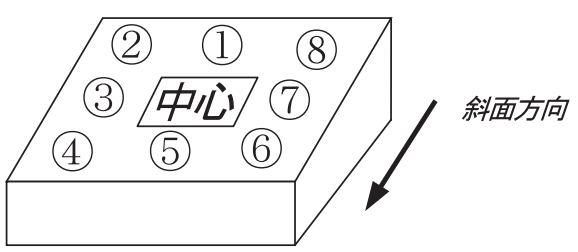

図-4 水準測量の観測地点図

Fig. 4 Observation points in leveling.

考えられる。また，測深棒では1地点に対し1回のみ 観測を実施したため, 測深棒による空間代表性を評 価する必要がある。まず，現地のある地点において， そこを中心に距離 $1.5 \mathrm{~m}$ の円状に8地点水準測量を実 施した，そこで中心からのずれを8地点（図一41)～(8) で求め, その平均から誤差を評価した。

\section{VI. 結果と考察}

\section{1. 誤差評価}

\section{1）姿勢誤差}

姿勢誤差は，GPS受信機を台車に固定した時の測 位結果と，実際にGPS受信機を背負った時の測位結 果との差の絶対值を求めることから算定した。100点 のデータにより算定した差の絶対值の平均は $0.16 \mathrm{~m}$ であり, 差の絶対值は $0.08 \mathrm{~m} \sim 0.24 \mathrm{~m}$ 範囲に分布し た．直線の区間は直立して滑走するため，姿勢変化が 少ないが，カーブを曲がる際にそれが大きくなると考 えられる。基本的に直立姿勢から伸び上がる動作はほ とんどなく，しゃがむ動作が多いため，すべての点に おいてスノーボードで観測した方が受信局を台座に固 定して観測した標高よりも小さな值となった.

\section{2）計算誤差}

計算䛊差の評価結果を表一1に示す。なお, 表内最 近隣法の欄の $0.5 \mathrm{~m}$ などの距離は, 前述のとおり地 表面標高, 積雪面標高2つのデー夕間の距離がその範 囲内に収まるデー夕のみを抽出したものである。表 の中の誤差は200点ほどのデータから求めたものであ り, 誤差はその絶対值の平均から求めた. 表一1か

\section{表 -1 計算誤差}

Table 1 Calculation error.

\begin{tabular}{l|r|r|r|c}
\hline & \multicolumn{3}{|c|}{ 最近隣法 } & 2 点幾何補間法 \\
\hline 補間距離 & $0.5 \mathrm{~m}$ & $1.0 \mathrm{~m}$ & $1.5 \mathrm{~m}$ & \\
斜度 $4^{\circ}$ & 0.02 & 0.03 & 0.04 & 0.02 \\
斜度 $8^{\circ}$ & 0.04 & 0.06 & 0.09 & 0.03 \\
斜度 $16^{\circ}$ & 0.17 & 0.12 & 0.16 & 0.06 \\
\hline
\end{tabular}


ら，斜度が大きくなるにつれて，また，抽出範囲が 広くなるにつれて, 誤差が増大する傾向にあること が分かる。しかし, 斜度 $16^{\circ}$ では補間距離 $0.5 \mathrm{~m}$ の時 の誤差が最も大きい。これは, 補間の際, 抽出した 点が等高線方向にずれているものが多かったためで あると考えられる．200点の個々のデー夕をみると， 林道の代表斜面である $4^{\circ}$ の誤差は補間距離が $1.5 \mathrm{~m}$ においても最大 $0.06 \mathrm{~m}$, 山頂付近の代表斜面である $16^{\circ}$ の誤差は最大 $0.20 \mathrm{~m}$ の值をとった。 2点幾何補間 法についても同様に斜度増加に対し誤差も増加する が, 最近隣法に比べ良好な值が得られた。

\section{3）実地誤差}

実地誤差は $0.16 \mathrm{~m}$ となった。これは, 観測点毎の 誤差の絶対值の平均となる. 水平方向の誤差は $5 \mathrm{~cm}$ 程度であったため, 標高方向には最大で $1.5 \mathrm{~cm}$ 程度 の誤差しか生まれない。そのため,ここではそれに ついては議論しない. 観測された時の衛星状況によ り精度は変動し, 最大で $0.20 \mathrm{~m}$ 程の誤差が生じる点 も存在するが，誤差は概ね $0.10 \mathrm{~m}$ 前後となる。この 誤差は，大気の状態や電子基準点からの距離により GPS観測機器自体が生じる誤差となるため, 技術向 上により改善され得るものである。

\section{4）観測誤差}

観測誤差の結果を表一2に示す。観測誤差は，8地 点それぞれの䛊差の絶対值を平均したものである. 地表面標高1739 m地点は山頂付近であり, 地形が 複雑なため測定地点ごとのばらつきが大きくなっ た. $1664 \mathrm{~m}$ 地点は尾根中腹, それ以降が林道とな るが，林道は尾根に比べ勾配も小さく，地形が安定 しているため, 山頂付近に対し, 林道付近の誤差は その $26 \sim 52 \%$ 程度である。

本研究では，時間的な制約により，測深棒による 観測を1地点に対し1回のみ行ったが, 山頂付近では 地形が複雑になっているため, 何度か実施する必要 があると考えられる。そのほかの地点に関しては, 概ね良好な結果であるといえる。

\section{5）GPS測位と測深棒による測量の比較}

表一3にGPS測位と測深棒による測量の比較, 表一 4に前述で評価した斜度別の誤差の合計值を示す。な

$$
\text { 表 }-2 \text { 観測誤差 }
$$

Table 2 Observation error .

\begin{tabular}{|c|c|c|c|c|c|c|}
\hline 地考 & & 1739 & 1664 & 1479 & 1411 & 1265 \\
\hline 誤 & 差 & 0.32 & 0.17 & 0.08 & 0.11 & 0.10 \\
\hline
\end{tabular}

お，表一3の值は測深棒観測值から GPS測位值を差し 引いた絶対值となる。 また, 誤差の合計は本研究で評 価した誤差が，偶然誤差であるため，ランダムウォー クの理論に基づき, 誤差の和は単純な足し算ではな く平方和の $1 / 2$ 乗となる. そのため, 三平方の定理を 用いてそれぞれの誤差を足し合わせた（Lichten， 2004).

まず最近隣法について注目すると，平均值におい ては, 表一4で求めた誤差の合計の中に, 表一3の GPS測位結果と測深棒観測と比較して求めた誤差が ほぼ収まる。

観測日毎に見ると。降雪期には誤差が大きいが， 融雪期に入ると誤差が誤差評価により求めたものの 中に含まれるようになる。これは, 測深棒観測にお いて, 道の脇で実施した際, 脇の溝や, 植生に影響 され，不正確な積雪深の観測となったことが誤差増 大の一つの要因であると考えられる。また，本研究 では1地点に対し1回の観測しか行わなかったことが 原因であるとも考えられる。しかし, 各観測日の誤 差の大部分が誤差評価により求めた誤差内（表一3の 平均欄）に含まれ, 誤差が $20 \mathrm{~cm}$ であれば, $2 \mathrm{~m}$ の積 雪深を仮定すると相対誤差は $10 \%$ となり良好な值が 得られるといえる。このことから, 積雪深が大きい ほど相対誤差は小さくなり GPS測位の優位性が際立 つといえる。

一方，2点幾何補間法には各観測日の值が誤差評価 により求めた誤差内（表一3の平均欄）に含まれるも のは少ない.この原因として考えられることは，2点

\section{表-3 GPS測位と雪尺観測の比較}

Table 3 Comparison of GPS survey with snow scale.

\begin{tabular}{l|c|c|c|c|c|c}
\hline & \multicolumn{3}{|c|}{ 最近隣法 } & \multicolumn{3}{|c}{ 2 点幾何補間法 } \\
\hline 斜面勾配 & $4^{\circ}$ & $8^{\circ}$ & $16^{\circ}$ & $4^{\circ}$ & $8^{\circ}$ & $16^{\circ}$ \\
\hline 1月29日 & 0.49 & 0.43 & & 0.37 & 0.33 & \\
2月19日 & 0.25 & 0.43 & 0.14 & 0.40 & 1.10 & 1.80 \\
3月4日 & 0.14 & 0.30 & & 0.20 & 0.69 & \\
4月2日 & 0.10 & 0.27 & 0.09 & 0.39 & 0.26 & 0.34 \\
4月13日 & 0.15 & 0.08 & & 0.28 & 1.14 & \\
\hline 平 均 & 0.23 & 0.30 & 0.12 & 0.34 & 0.70 & 1.10 \\
\hline \multicolumn{1}{|c}{} & \multicolumn{4}{c}{ 単位 $(\mathrm{m})$}
\end{tabular}

表 -4 斜度別の誤差合計値

Table 4 Total error in each grade.

\begin{tabular}{c|c|c|c}
\hline 斜 度 & $4^{\circ}$ & $8^{\circ}$ & $16^{\circ}$ \\
\hline 最近隣法 & \pm 0.25 & \pm 0.29 & \pm 0.41 \\
2点幾何補間法 & \pm 0.25 & \pm 0.28 & \pm 0.40 \\
\hline \multicolumn{4}{|c}{} \\
\hline
\end{tabular}




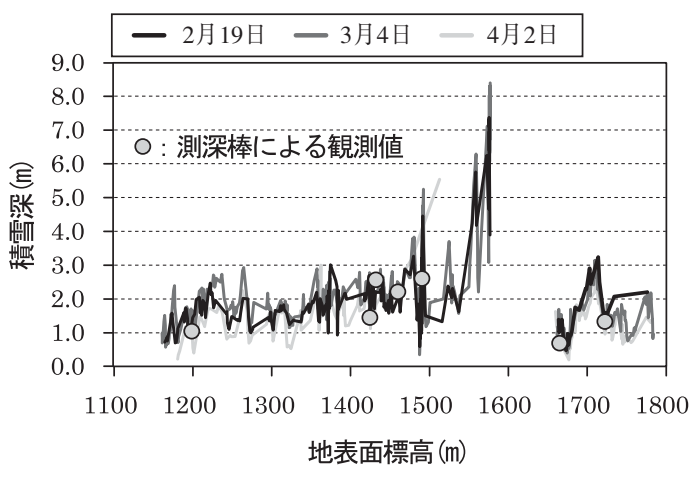

図-5 GPS測位結果

Fig. 5 Results of survey using GPS.

幾何補間法に仮の積雪深を用いたことである。これ は，標高補正をする際に用いたものだが，図一5を見 る通り積雪深は地表面標高方向に一定ではないため, 補間がうまくいかず，このような結果となったと考 えられる。

しかし, 計算誤差の検討からも分かる通り（表一 4), 補間法としては最近隣法よりも誤差が少ないた め, 上手く標高補正のための地表面標高デー夕を選 ぶことができれば誤差も想定範囲内に収まると考え られる。方法としては，仮の標高を用いず，最近隣 法と組み合わせることで改善させることができると 考える.

\section{GPS測位による積雪深観測}

GPS測位掞よび各補間法を用いて算定した標高と 積雪深の関係を図一5に示す。煩雑さを避けるため, 2月19日，3月4日，4月2日の観測結果のみを載せた. なお地表面標高 $1550 \mathrm{~m} \sim 1650 \mathrm{~m}$ 付近は無積雪期に 植生があり，尾根線に侵入することが不可能であ り, 地表面標高データが取得できなかったため欠測 となっている，山頂部に関しては，別ルートで山頂 まで登り下れるところまでを測位した。

\section{1）経時変化}

各観測日の標高と積雪深の回帰直線の勾配に注目 する (表一5)。林道区間は積雪期である 2 月は $4 \mathrm{~mm} / \mathrm{m}$ の増加率であるが，融雪初期の3月には $11 \mathrm{~mm} / \mathrm{m}$ と 非常に大きな増加率となる。これは，融雪が気温に 大きく影響されることに起因すると考えられる。融 雪初期は, 地表面標高の高い地点では気温が上がら ずさほど融けないが，低い地点では気温がプラスに
表 -5 直線回帰式の傾き

Table 5 Gradient of regression line.

\begin{tabular}{c|c|c|c}
\hline & 2 月19日 & 3月4日 & 4 月2 日 \\
\hline 林道区間 & 4 & 11 & 4 \\
森林限界上 & 16 & 2 & 3 \\
\hline \multicolumn{4}{|c}{ 単位 $(\mathrm{mm} / \mathrm{m})$}
\end{tabular}

転じる時間が長くなり，融雪が進む．融雪後期の4月 になると地表面標高の高い地点でも融雪が進んだた め, 回帰直線勾配がまた小さくなると考えられる。

森林限界上は積雪期と融雪期の増加率が大きく異 なる。これは, 風による雪の移動や, 日射の影響な どにより変化したとも考えられるが, 図一5の地表面 標高 $1650 \mathrm{~m}$ 以降のグラフを見ると積雪深は一度 $1700 \mathrm{~m}$ 付近で増加し, その後減少していることか ら, 山麓から山頂までの積雪深分布は線形では正確 に増加率をうまく表現できていない可能性がある。

局所的にみると, 標高 $1300 \mathrm{~m}$ 付近で積雪深がほか に比べて小さい部分がある。ここは，林道とスキー 場との合流地点があり他の林道区間に比べ道幅も広く 開けている，そのため，風による雪の移動，また，日 射による融雪が進んだと考えられる。加えて, 現地の 観察でさほど大きくはなかったが，雪上車が通った 跡があり，それによる圧雪の影響も多少あるかもし れない。

\section{2）空間分布}

図一5を見ると，どの観測日も林道区間はほぼ線形 に増加し, 森林限界以降積雪が減少している。林道 を抜けて尾根区間に入ると積雪深は増加し， $8 \mathrm{~m}$ ほ どまで達する。この付近は，春先に蔵王エコーライ ン（図一1）が除雪されたのちにできた両脇の雪壁が 目算で $6 \mathrm{~m}$ 程の高さがあったため, 観測結果は的外 れな值ではない。これまでのスノーサーベイではこ れほどの積雪深を観測することは非常に困難であっ たため，積雪深観測にGPS測位を用いる優位性を示 せた。

細かく見ると $1500 \mathrm{~m}$ 付近で積雪深が一旦落ち込ん でいる部分が見受けられる。この区間は林道から蔵 王エコーラインに合流している点でかなり開けてい る場所である。また，この区間は斜度が4程である ため雪崩などによる雪の移動は考えられないため, 風や日射による融雪が進んだと考えられる.

このように，GPSを用いた観測では地表面の起伏 変化による積雪深の変動をとらえることができた。 


\section{VII.まとめ}

本研究でGPSを用いた積雪深観測の有用性につい て確認することができた。従来のスノーサーベイで は測量出来ない深さでも地表面標高デー夕と積雪面 標高データがあれば容易に積雪深を求めることがで きる、GPSによる観測の結果, 地表面標高 $1500 \mathrm{~m}$ 付 近での地表面の起伏変化による積雪深の落ち込みや 山頂付近での積雪深の減少傾向など，標高に対する 積雪深分布の連続的な観測ができたことは将来の山 岳積雪モデルの検証に有効である. 対象領域に関し て,この観測方法で最も重要なのは地表面標高デー 夕を正確に幅広く取得するということである。地表 面の標高データさえ正確に取得されていれば, 測定 範囲内のどの部分を後日滑ろうが積雪深を求めるこ とができる.

䛊差合計に関しては, 最近隣法で, 斜面 $4^{\circ}, 8^{\circ}$, $16^{\circ}$ でそれぞれ， $\pm 0.25 \mathrm{~m}, \pm 0.29 \mathrm{~m}, \pm 0.41 \mathrm{~m}, 2$ 点幾 何補間法ではそれぞれ $\pm 0.25 \mathrm{~m}, \pm 0.28 \mathrm{~m}, \pm 0.40 \mathrm{~m}$ となった．数值上 2 点幾何補間法の方が良好である が，2点幾何補間法の際の仮の表高による誤差が含ま れていないため, 実際の結果としては最近隣法の方 が良好な值となる。浜田ら（1996）や堀ら（2003） によるGPS測位との測位精度の比較をすると, それ ぞれが, 数センチの精度であることから, 本研究で の精度は, 少々劣る。しかし, 使用機器, 解析ソフ 卜, 観測環境などにより精度は異なるため比較は単 純にはできない. 本研究で用いたGPS (Promark3) の 公称精度が $\pm 0.10 \mathrm{~m}$ 程度である。本研究での GPS測 位機器の誤差を検討した結果である実地誤差が $0.16 \mathrm{~m}$ であることを考えると, GPSに関しては冬季の山岳 域でも十分使用が可能であるといえる.

しかし, 本研究のように植生などの影響により, 地 表面標高デー夕を取得できない場合, 積雪深も欠測 となる。また, 観測の際は, 突然の吹雪や雪崩など には十分な配慮が必要である。それゆえ, 観測区域 の選択も重要な要素となる。本研究ではスノーボー ドを用いたが，観測手段に関しても考慮の余地は残 されているであろう。いずれにせよ, 本研究で示し た方法は, 従来の観測方法に比べ, 連続的に, 容易 に積雪深観測を可能にする。

\section{謝辞}

本研究を進めるにあたり, 環境省の地球環境研究 総合推進費（S-4）：温暖化の危険な水準及び温室効 果ガス安定化レベル検討のための温暖化影響の総合 的評価に関する研究, 日本大学学術フロンティアプ ロジェクトと東北建設協会の助成を受けた。また, (株) ジオサーフ橋本靖彦氏, 竹添明生氏, (株) 仙台 測器社渋谷仁氏からGPS利用についての助言を頂い た。また, 東北大学大学院環境科学研究科（実測当 時）浜本洋さんには，実測の際，同行して登山指導 をして頂いた。なお, 本研究のアイディアは森林総 合研究所の大丸裕武氏との対話から得た。ここに記 して感謝の意を表す。

\section{参考文献}

源島良一・松井保幸（2003）：より効率的な高速道路の整備にむ けて 第二東名高速道路 (静岡県内) における技術開発事例, 土 木学会誌, 88, pp.44-46.

浜田賢二·外柜保 勝-中井 修·林 忠夫 ·清水則一・ 中川浩二 (1996) : リアルタイムGPS海上測位システムの実海域実験と実 用性の検証, 土木学会論文集, 30IV, pp.19-30.

堀 宗朗・小国健二・望月一浩・菅野高弘（2003）：RTK-GPSを 用いた地盤大变状の計測と精度の検証, 土木学会論文集, 62 III, pp.177-183.

気象庁: 積雪計/観測の原理,

http://www.jma.go.jp/jma/kishou/know/kansoku_guide/e1.htm. (参照:2006/01/12)

気象庁: 気象観測所一覧, 2008/07/24,

http://www.jma.go.jp/jma/kishou/know/amedas/ame_master.pdf. (参照: 2008/08/18)

松山 洋 (1998a): 巻機山における積雪密度・積雪水当量の季 節変化と高度分布, 水文・水資源学会誌, 11, pp.117-127.

松山 洋 (1998b): 日本の山岳地域における積雪水当量の高度 分布に関する研究について, 水文・水資源学会誌, 11, pp.164174.

村上茂樹・山野井克己（2003）: 宝川森林理水試験地における積 雪水量の高度分布の長期変化, 水文・水資源学会誌, 16, pp.131141.

内閣府: 平成18 年豪雪による被害状況等について (第9報), 2006/09/26,

http://www.bousai.go.jp/kinkyu/2005yuki-higai/2005yuki-higai_9.pdf. (参照: 2007/01/12)

（社）日本雪水学会監修 (2005): 雪と氷の事典, 朝倉書店, pp.681682.

島村雄一・泉 岳樹・松山 洋 (2005): スノーサベイとリモート センシングに基づく山地積雪水資源量の推定一新潟県上越国境 周辺を事例に一, 水文・水資源学会誌, 18, pp.411-423.

Lichten, W. (2004): 計測データと誤差解析の入門 (村上雅章 訳), ピアソン・エデュケーション, pp.47-50.

(受付：2008年8月 12 日，受理：2009年2月2日） 


\title{
Snow Depth Measurement by Snowboarding with Kinematic GPS
}

\author{
Keita KIKUCHI ${ }^{1)}$ So KAZAMA ${ }^{2)}$ \\ 1) Graduate School of Engineering, Tohoku University \\ (6-6-06, Aoba, Aramaki, Sendai, 980-8579, Japan) \\ 2) Graduate School of Environmental Studies, Tohoku University \\ (6-6-20, Aoba, Aramaki, Sendai, 980-8579, Japan)
}

Temporal changes of spatially varying snow depth were measured using GPS technique in mountainous area of Miyagi Zao from winter to spring in the season of 2006-07. In the mountainous areas, because the elevation-snow depth distribution data are hardly obtained from snowy season to snowmelt season, these data are valuable. We used the GPS kinematics surveying system, which is in higher reliability for the interferometric positioning of the observation. This method is capable of recording the observations at any point in short and constant time intervals. Two interpolation methods; the nearest neighbor method and 2-point geometric method, were used. By interpolating the GPS observation in both methods, we prepared detail snow depth distribution data corresponding to ground elevation. Observation errors include the error by position change, the calculation error, the morphologic error and the error induced by the snow scale. The total errors induced from above practices are in the range of $0.25 \mathrm{~m} \sim 0.41 \mathrm{~m}$ from nearest neighbor method and $0.25 \mathrm{~m} \sim 0.40 \mathrm{~m}$ from the 2-point geometric method, respectively. The error of 2-point geometric method using GPS ranges $0.34 \mathrm{~m} \sim 1.10 \mathrm{~m}$ in comparing with snow depth measured by snow scale. On the other hand, the error of the nearest neighbor method using GPS observation is $0.12 \mathrm{~m} \sim 0.30 \mathrm{~m}$. This result, therefore, suggests that the GPS survey with nearest neighbor method is an effective method of observation in mountainous area which gives the precise measurement with the error less than $10 \%$ of total snow depth, when the snow depth is more than $3 \mathrm{~m}$.

Key words : kinematic surveying, nearest neighbor method, 2-point geometric method, snow depth-elevation curve, error evaluation 